\title{
NUTRITIONAL STATUS OF TODDLERS IN NAGARAKEMBANG VILLAGE, CINGAMBUL DISTRICT, MAJALENGKA REGENCY
}

\author{
Ai Nurasiah, Merisa Laora Heryanto, Ila Ayatilah \\ STIKes Kuningan \\ ainurasiah@gmail.com
}

\begin{abstract}
The coverage of visits to the integrated service post for boys and girls in the village of Nagarakembang in January 2019 was $26.82 \%$, in February it was 42.54\%, in March $81.16 \%$. The purpose of this study was to describe the nutritional status of children under five based on the frequency of visits to integrated service posts in Nagarakembang Village, Cingambul District, Majalengka Regency. This type of research is descriptive with a cross sectional design. The sampling technique is total sampling with a sample of 85 toddlers aged 25-60 months The results showed that the toddlers who often visited the integrated service posts were $47.1 \%$. The nutritional status of children under five was mostly normal, which was $82.4 \%$. Respondents who frequently visited the integrated service posts were mostly with normal nutritional status, namely 31 toddlers. Conclusion: There are as many toddlers who do not visit the integrated service posts as children who visit the integrated service posts and on average have nutritional status. Suggestions for mothers of toddlers must be active in visiting integrated service posts so that they have knowledge about additional food for toddlers.
\end{abstract}

Keywords: Integrated Service Posts; Nutritional Status

\section{Introduction}

The most important period for a toddler, the first two years of life is called the golden period. This period is a critical point for the growth and development of toddlers. Nutrient needs cannot be met, then nutritional disorders can occur at that time and will have an impact on the future
(PlaceholderI)Nutritional status is a condition in which the human body can have an impact on food consumption and use of nutrients. Nutritional status is divided into 2 factors, namely direct factors and indirect factors. Food intake and infectious diseases are factors that directly cause nutritional status, while mother's 
knowledge about nutrition, weaning age, low birth weight (LBW), feeding too early, family size, child care patterns, environmental health, and health services are factors that cause status indirectly (Wahyuni, 2009).

The results of (Riskedas, 2013) showed that nationally, the coverage of weighing children under five as a means of monitoring the nutritional status of the health centers was $65.7 \%$ (Riskedas, 2013). The frequency of visits by toddlers to integrated service posts decreases with increasing age of children. As an illustration, the proportion of children 6-11 months who are weighed at the integrated service posts is $91.3 \%$, for children $12-23$ months it drops to $83.6 \%$, and at $24-35$ months it drops to $73.3 \%$.

Baby visits are aimed at increasing babies' access to basic health services, knowing as early as possible if there are abnormalities in babies so that they get help quickly, health care and disease prevention through growth monitoring, immunization, and improving the quality of life of babies by stimulating growth and development so that children's rights get health is fulfilled. The health of babies and toddlers must always be monitored to ensure that their health is always in optimal condition. Infant health services are one of several indicators that can be a measure of the success of efforts to improve the health of infants and toddlers. Health services for infants are aimed at babies aged 29 days to 11 months by providing health services in accordance with standards by health workers who have clinical health competence (doctors, midwives, and nurses) at least four times, namely at the age of 29 days -2 months, ages $3-5$ months, ages $6-8$ months and ages 9-12 months. This service consists of weighing, giving basic immunizations (BCG, DPT / HB1-3, Polio 1-4, DPT HB 123 and Measles), Stimulation of Early Development Intervention Detection infants, giving vitamin A to infants (6-11 months), counseling on infant health care as well as counseling on exclusive breastfeeding and complementary feeding. Coverage of infant health services in 2017 decreased by $3.5 \%$, coverage in 2016 was $102 \%$ and in 2017 it was $98.5 \%$. Based on the districts/cities the highest coverage of infant health services is Indramayu Regency, Cirebon Regency, Karawang Regency, Subang Regency, West Bandung Regency, Majalengka Regency, Kuningan Regency, Sumedang Regency, Banjar City, Bekasi Regency, Ciamis Regency, Tasikmalaya Regency, and Regency 
Sukabumi whose coverage reaches $100 \%$ (Kementerian Kesehatan Republik Indonesia, 2016).

Health service factors such as integrated service posts also affect the nutritional status of toddlers such as activeness in integrated service post visits kunjungan. One of the goals of the integrated service post is to monitor the improvement of the nutritional status of the community, especially children under five and pregnant women. The low understanding of families and communities about the benefits of integrated service posts will result in not optimal monitoring of the growth of toddler (Sihotang \& Rahma, 2017). The activeness of mothers in each integrated service post activity will certainly affect the nutritional status of toddlers. The coverage of children under five who are weighed describes the level of community motivation/participation in monitoring the growth and development as well as the health of children under five at the integrated service post. The coverage of the visit, the national percentage of children under five who are weighed at the integrated service post is $80 \%$ (Riskedas, 2013)

The success of the integrated service post can be seen from the SKDN coverage where $(\mathrm{S})$ is the total number of toddlers in the integrated service post area, $(\mathrm{K})$ the number of toddlers who have KMS, (D) toddlers who are weighed, $(\mathrm{N})$ toddlers whose weight has increased. Monitoring the growth of children under five in an area of $\mathrm{K}$ / S program coverage $>80 \%$ is said to be good $<80 \%$ is less, D / S participation> $80 \%$ is said to be good $<80 \%$ is less, N / D is said to be good $<80 \%$ is to be good $<80 \%$ is less (Legi et al., 2015)

Integrated service posts are a form of Community-Based Health Efforts which are managed from, by and for the community with technical support from health workers whose targets are the entire community. Weighing toddlers at the integrated service post is a government strategy set at the Ministry of Health to find out early about growth disorders in toddlers so that appropriate action can be taken immediately (Mubarak, 2012).

Some of the obstacles faced related to the visit of toddlers to integrated service posts, one of which is the level of family understanding of the benefits of integrated service posts. This will affect the activeness of mothers in visiting each integrated service post activity. Because one of the goals of the integrated service post is to monitor the improvement of nutritional 
status, especially in toddlers, in order to achieve this, mothers who have children under five should be active in integrated service post activities so that the nutritional status of their toddlers is monitored (Sukrayasa et al., 2018).

Some of the impacts experienced by toddlers, when mothers of toddlers are not active in integrated service post activities include not getting health education about normal toddler growth, not getting vitamin A for eye health, toddlers and mothers of toddlers not getting counseling about additional food. Mothers who often participate in integrated service post activities can monitor the growth and development of their toddlers (Kementerian \& Kesehatan, 2018)

Based on observations made by researchers in January-March 2019 at the Melati integrated service post, the coverage of visits (N) was obtained. In January, males and females were $26.82 \%$, in February males and females were $42.54 \%$, in March male and female $81.16 \%$.

Based on this background, the authors are interested in examining the description of the nutritional status of children based on the frequency of visits to integrated service posts in Nagarakembang Village, Cingambul District, Majalengka Regency.

\section{Method}

This type of research uses a descriptive type of research. The design used in this research is cross sectional. The population in this study were all toddlers aged 25-60 months who visited the integrated service post for toddlers, Nagarakembang Village from April to June totaling 85 toddlers. The sampling technique used is total sampling.

\section{Results}

Table 1 Respondents Frequency Distribution

\begin{tabular}{lcc}
\hline \multicolumn{1}{c}{ Variable } & Frequency (n) & Percentage (\%) \\
\hline Integrated Service Post Visits & & 47.1 \\
$\quad$ Often & 40 & 52.9 \\
Not Often & 45 & \\
Nutrition Status & & 8.2 \\
$\quad$ Less & 7 & 82.4 \\
Normal & 70 & 9.4 \\
Over & 8 & \\
\hline
\end{tabular}


Based on table 1 , it is known that most of the respondents who did not frequently visit the integrated service posts were $52.9 \%$ of respondents and the majority of respondents with normal nutritional status were $82.4 \%$ of respondents

Table 2. $\operatorname{xxxxxxxxxxx}$

\begin{tabular}{|c|c|c|c|c|c|c|c|c|}
\hline \multirow{3}{*}{$\begin{array}{c}\text { Integrated } \\
\text { Service Post } \\
\text { Visits }\end{array}$} & \multicolumn{6}{|c|}{ Nutrition Status } & \multirow{2}{*}{\multicolumn{2}{|c|}{ Total }} \\
\hline & \multicolumn{2}{|c|}{ Less } & \multicolumn{2}{|c|}{ Normal } & \multicolumn{2}{|c|}{ Over } & & \\
\hline & $\mathbf{F}$ & $\%$ & $\mathbf{F}$ & $\%$ & $\mathbf{F}$ & $\%$ & $\mathbf{N}$ & $\%$ \\
\hline Often & 4 & 10 & 31 & 77.5 & 5 & 12.5 & 40 & 100 \\
\hline Not Often & 3 & 6.6 & 39 & 86 & 3 & 6.6 & 45 & 100 \\
\hline
\end{tabular}

Based on table 2, it is known that most of the respondents with an infrequent visit frequency were as many as $45 \%$ of respondents.

\section{Discussion}

The results of the research in the village of Nagarakembang showed that it was known that most of the respondents did not often visit the integrated service post, as many as $52.9 \%$ of respondents. Mothers under five do not often visit integrated service posts because mothers under five are less motivated than cadres, if mothers under five visit integrated service posts, mothers under five can get knowledge about additional food, and their development and growth. This is in line with research, which shows that there is a significant relationship between family activeness variables in integrated service post activities with the nutritional status of their toddlers (Octaviani et al., 2008).

Families who are not active in integrated service post activities have a 6,857 times greater risk of being affected by the nutritional status of KEP compared to families who are not active. This is supported by research by Cut (Nazri et al., 2015) which states that monitoring the nutritional status of children under five is the main reason mothers participate in integrated service posts (Nazri et al., 2015). Mothers who are satisfied with the integrated postal service are more likely to attend than those who are dissatisfied. Respondents with an intention to participate in an integrated service post every month are more likely to attend than those who do not intend to attend every month. Based on 
the results of this study indicate that the reason for the activeness of mothers in integrated service post visits is to monitor nutritional status so that with routine monitoring it is hoped that toddlers will have good nutritional status and early detection of poor nutritional status can be carried out.

According to (Yulifah \& Yuswanto, 2014), factors that affect compliance with integrated service post visits, one of which is education. Parents' education is an important factor in children's development. With a good education, parents can receive all information from outside, especially about good parenting, how to maintain their children's health, education, and so on (Yulifah \& Yuswanto, 2014). This is also supported by research by (Reihana \& Duarsa, 2012) that there is a relationship between maternal education and maternal participation in weighing toddlers to integrated service posts (Reihana \& Duarsa, 2012)

Compliance with coming to the integrated service post is influenced by several factors, according to research results (Anwar et al., 2010) stated that not visiting the integrated service post every month has various reasons. The main reason given by mothers for high participation is that their children are still asleep and they are busy. So, they cannot bring their children to the integrated service post. Only a small number of mothers have reasons that their children have received complete immunizations, so they do not feel like they come to the integrated service post every month (Anwar et al., 2010). There are various reasons that can be seen, it is necessary to have an understanding of integrated service posts and their benefits so that mothers can be more motivated to bring their children to integrated service posts.

Looking at the results of the research on nutritional status, it is known that most of the respondents with normal nutritional status are $82.4 \%$ of respondents, and some children under five have low nutritional status, this is because the mothers under five have less knowledge about nutritious food because they are less active in the integrated service posts. This nutritional status is important because it is a risk factor for illness and death. Good nutritional status for a person will contribute to his health and also to the ability to recover. The nutritional status of the community can be known through an assessment of their food consumption based on quantitative and qualitative data 
(Harjatmo et al., 2017). Nutritional status indicators based on the $\mathrm{BMI} / \mathrm{U}$ index can be used to identify thin and fat. The problem of thin and fat at an early age can result in the risk of various degenerative diseases in adulthood (Simbolon, 2019).

According to (Soekirman et al., 2006), a family with a small income and a large number of family members will further aggravate the nutritional status of children under five (Soekirman et al., 2006). In a developing country such as Indonesia, where the economic level of the people is mostly the lower middle class, this can have an impact on meeting food needs, especially nutritious food. (Simbolon, 2019) states that daily food intake that contains nutrients in the type and amount according to the body's needs by paying attention to the principles of food diversity or variation, physical activity, cleanliness and ideal body weight greatly affects the nutritional status of toddlers, in addition to community behavior. related to health maintenance, for example eating nutritious foods (Simbolon, 2019).

Looking at the results of the study, it is known that most of the respondents do not often make visits to the integrated service post, which is as much as $45 \%$. In the routine activities of the integrated service post, there are also counseling services, useful counseling for the community or mothers to increase knowledge about health and nutrition, so that when applied in daily life, a healthy lifestyle will be realized for their families. The higher the protein energy intake in toddlers, the better their nutritional status so that physical and brain growth can work optimally.

The effect of an increase in income will have an impact on improving nutritional status and family conditions, generally when income increases, the amount and type of food tends to improve as well. The level of income will determine what type of food will be purchased with this money, the higher the income, the higher the percentage used to buy fruit, vegetables and various other types of food.

According to (Sulistyoningsih, 2015), the direct cause of malnutrition in toddlers is the presence of infectious diseases and food consumption that is not sufficient for their needs, while the indirect causative factor is a supporting factor for the emergence of malnutrition problems in children under five is the mother's lack of knowledge about health, socioeconomic ( purchasing power) is still low, food availability at the family level is not 
sufficient, consumption patterns are not good, and health service facilities are still difficult to reach (Sulistyoningsih, 2015). This is also in accordance with the theory put forward by (Supariasa, 2017) which states that there are two causes that cause malnutrition, one of which is the indirect factor, namely health maintenance (Supariasa, 2017).

The results of this study also show that mothers of toddlers do not often visit the integrated service post because mothers of toddlers are less motivated from cadres, if mothers of toddlers visit the integrated service post, mothers of toddlers can get knowledge about additional food, and their development and growth can also be monitored. Most of the toddlers in this Nagarakembang village do not gain weight, it is possible that mothers of toddlers lack knowledge about nutritious food because mothers of toddlers are less active in visiting integrated service posts.

\section{Conclusion}

Most of the respondents who frequently visited the integrated service post mostly had normal nutritional status as many as 31 toddlers, $36 \%$.

\section{Suggestion}

It is recommended that mothers who have active toddlers follow routine integrated service post activities because they are important and beneficial for the growth and health of toddlers.

\section{Reference}

Anwar, F., Khomsan, A., Sukandar, D., Riyadi, H., \& Mudjajanto, E. S. (2010). High participation in the Posyandu nutrition program improved children nutritional status. Nutrition Research and Practice, 4(3), 208.

Dasar, R. K. (2013). Kementrian Kesehatan Republik Indonesia. Kementrian Kesehatan Republik Indonesia, 87-90.

Harjatmo, T. P., Par'i, H. M., \& Wiyono, S. (2017). Penilaian status gizi. Kementerian Kesehatan Republik Indonesia. Jakarta.

Kementerian, \& Kesehatan, R. . (n.d.). Buku Saku Pemantauan Status Gizi Tahun 2017.

Kementerian Kesehatan Republik Indonesia. (2016). Profil Kesehatan Indonesia 2016. In Profil Kesehatan Provinsi Bali. http://www.depkes.go.id/resources/do wnload/pusdatin/profil-kesehatanindonesia/Profil-Kesehatan-Indonesia2016.pdf

Legi, N. N., Rumagit, F., Montol, A. B., \& Lule, R. (2015). Faktor yang berhubungan dengan keaktifan kader posyandu di wilayah kerja Puskesmas Ranotana Weru. Jurnal GIZIDO, 7(2), 429-436. 
Mubarak, I. W. (2012). Ilmu Kesehatan Masyarakat. Salemba Medika.

Nazri, C., Yamazaki, C., Kameo, S., Herawati, D. M. D., Sekarwana, N., Raksanagara, A., \& Koyama, H. (2015). Factors influencing mother's participation in Posyandu for improving nutritional status of children under-five in Aceh Utara district, Aceh province, Indonesia. BMC Public Health, 16(1), 1-9.

Reihana, R., \& Duarsa, A. B. S. (2012). Faktor-faktor yang berhubungan dengan partisipasi ibu untuk menimbang balita ke posyandu. Jurnal Kedokteran Yarsi, 20(3), 143-157.

Sihotang, H. M., \& Rahma, N. (2017). Faktor Penyebab Penurunan Kunjungan Bayi di Posyandu Puskesmas Langsat Pekanbaru Tahun 2016. Jurnal Endurance: Kajian Ilmiah Problema Kesehatan, 2(2), 168-177.

Simbolon, D. (2019). Pencegahan Stunting Melalui Intervensi Gizi Spesifik Pada Ibu Menyusui Anak Usia 0-24 Bulan. Surabaya: Media Sahabat Cendekia.

Soekirman, S. S. W., Djoko, S., \& Soenardi, T. M. (2006). Hidup Sehat Gizi Seimbang dalam Siklus Kehidupan Manusia. Jakarta: PT Primamedia Pustaka.

Sukrayasa, I. W., Martiningsih, I. E., \& Agung, I. G. A. A. (2018). Strategi Pemberdayaan Kader Posyandu untuk Meningkatkan Program Gizi di Kecamatan Denpasar Utara. Jurnal Ilmu Gizi: Journal of Nutrition Science, 7(2), 42-48.
Sulistyoningsih, H. (2015). Gizi Untuk Kesehatan Ibu dan Anak. Graha Ilmu.

Supariasa, I. D. N. (2017). Ilmu Gizi Teori Dan Aplikasi. Buku Kedokteran EGC Indonesia.

Wahyuni, I. S. (2009). Hubungan Tingkat Pengetahuan Ibu tentang Gizi dengan Status Gizi Anak Balita di Desa Ngemplak Kecamatan Karangpandan Kabupaten Karanganyar. Universitas Sebelas Maret.

Yulifah, R., \& Yuswanto, T. J. A. (2014). Asuhan Kebidanan Komunitas Edisi 2. Jakarta: Salemba Medika. 